\title{
Factorial Dimensions of Employee Engagement in Public and Private Sector Banks
}

\author{
Dr.P. Amirtha Gowri and Dr.M. Mariammal
}

\begin{abstract}
Employee engagement is the level of commitment and involvement an employee has towards his organization and its values. An engaged employee is aware of business context, and works with colleagues to improve performance within the job for the benefit of the organization. It is a positive attitude held by the employees towards the organization and its values. This paper focuses on the assessment of three factors namely 'Commitment', 'Salary and benefits' and 'Job satisfaction' which ultimately decide employee engagement in public and private sector banks. 55 respondents from public sector banks and another 55 respondents from private sector banks were selected at random by adopting convenient sampling technique. The factors that grounds employee engagement is identified and they are assessed with descriptive statistics like mean and standard deviation and Pearson's product moment correlation is applied to find out their inter-relationship with each other. One way ANOVA test is also used to find out the relationship between the employee engagement factors and the demographic and other variables of the bank employees. Besides, suitable suggestions are also promulgated for better employee engagement in public and private sector banks.
\end{abstract}

Keywords--- Employee Engagement, Factorial Dimensions, Private Sector Banks, Public Sector Banks

\section{INTRODUCTION AND NEED FOR THE STUDY}

$\mathrm{I}^{\mathrm{N}}$ $\mathrm{N}$ the fast paced milieu, organizations are facing an increasingly competitive situation. The advent of multinational corporations and world-wide tie-ups paved way for precocious development in information technology and communication. Rising perplexity in carrying out business activities, urge to become world class business units, shortage of workforce with discerning prowess and sprouting technological advancements lead to snag in most organizations on magnetizing, reserving and contriving human talents [1]. Every organization wants to reap beneficial features over others and employee engagement is the pre-eminent tool for it. Employee engagement is the level of commitment, enthusiasm and involvement an employee has towards his chore which can be deliberately seen in his/her fidelity towards the work.

Dr.P. Amirtha Gowri, Associate Professor and Head of the Department of Management Studies, Dr. Sivanthi Aditanar College of Engineering, Tiruchendur 628215, Thoothukudi District, Tamilnadu, South India. Email:soundargowri@yahoo.com

Dr.M. Mariammal, Assistant Professor of Commerce, Govindammal Aditanar College for Women, Tiruchendur 628215, Thoothukudi District, Tamilnadu, South India. E-mail:bhvnmani@yahoo.co.in

DOI: 10.9756/BIJDM.3065
In today's highly competitive structure, organizations can achieve unexceptionable levels of performance only when workforce reveals tenacious commitment towards their errands. Higher productivity, reliability, higher self motivation, confidence to express new ideas, loyalty towards organization, reduced employee turnover and lower absenteeism are some of the attributes of a wholly engaged employee, who in turn act as valuable assets of an organization. Now-a-days banks being at competitive situation, employee engagement is very much crucial for longer sustainability. This study arises from the need to manage the human resources of the banks more effectively. Having an engaged workforce with it is important because it helps banks to reap benefits of sustainability, productivity and increased efficacy. Thus in this study, an attempt has been made by the researchers to find out the factorial dimensions of employee engagement in public and private sector banks.

\section{Literature REVIEW}

Boon et al [2] and Saima [2] identified four Human Resources Management practices namely teamwork, empowerment, reward and communication. Their results show that these Human Resources Management Practices are positively related with job engagement of employees. Denison [1] reports that organizations in which employees were participative in decision-making practices at higher levels have showed more employee engagement and their financial performance relative to their opponents gradually increased. Junghoon Lee [3] found that the important determinant of employee engagement at work, is their positive selfevaluation. In order to have higher levels of employee engagement the organizations should keep this evaluation as the starting point and should attempt to retain their workforce. Hafiz Abdur Rashid et al [2] found that employee engagement inclination differs from department to department on employee to employee basis and employee's mind-set toward employee engagement is also different. Swatee Sarangi and Srivastava [2] has identified key dimensions of organizational culture and communication which can shape employee engagement in banks. Evidence of May et al [2] suggested that the emotional experiences and well being are related to employee engagement. Beverly Little and Philip Little [2] recognized that the employee engagement demonstrates its relationship to resultant variables is important to every organization, such as productivity, safety, employee retention and customer service. Abdul Khaliq Alvi and Abdus Sattar Abbasi [2] stated that reducing employee turnover, improving organizational productivity and long term commitment of workforce is possible to senior practitioners in banking sector by erecting justice in all procedures and systems. 


\section{OBJECTIVES}

The following are the main objectives of the study:

1. To find out the inter-relationship between the employee engagement factors and overall employee engagement in public and private sector banks; and

2. To decipher the relationship between the employee engagement factors and the demographic and other variables of the public and private sector bank employees.

\section{METHODOLOGY}

This section describes the methodology which includes the collection of data, the construction of questionnaire and the pre-test, the sampling size and fieldwork and the framework of analysis.

\subsection{Collection of Data}

The study is based on both primary and secondary data. The primary data were collected from the bank employees in public and private sector banks directly with the help of a structured questionnaire. Secondary data were collected from journals and websites.

\subsection{Construction of Questionnaire}

The questionnaire used for the study consists of two parts. The first part relates to the demographic and other variables of the bank employees and the second part comprises Employee Engagement Scale (EES). To find out the employee engagement, the researchers have developed their own scale. The review of literature and the pilot study formed the base for the development of Employee Engagement Scale. It comprises of 35 items categorized into 3 factors, namely commitment (15 statements), salary and benefits (5 items) and job satisfaction (15 items). All the items are rated on a five point scale.

\subsection{Sampling Size and Fieldwork}

The present study has been carried out in Tiruchendur area which covers, Arumuganeri, Kurumbur, Nalumavadi, Sonakanvillai and Authoor. 55 samples from public sector banks and another 55 samples from private sector banks were selected at random by adopting convenient sampling technique. The field work for the study was conducted during June and July 2012.

\subsection{Framework of Analysis}

The data collected with the help of questionnaire are analyzed with the help of descriptive statistics like mean, standard deviation, Pearson's product moment correlation and ANOVA. A master table was prepared for entering the responses of each employee and small cross tables were made from the master table for analysis.

\section{HYPOTHESES FRAMED}

The null hypotheses framed for the present study are,

1. The various factors of employee engagement are not significantly related with the overall employee engagement in the public and private sector banks and
2. There exist no significant difference between the various employee engagement factors and the demographic and other variables of the public and private sector bank employees.

\section{ANALYSIS AND INTERPRETATION}

The analysis is carried out in the following parts:

\subsection{Application of Pearson's Product Moment Correlation}

Pearson's product moment correlation is used to find out the inter-relationship among the various factors of employee engagement.

\section{i. $\quad$ Public Sector Bank Employees}

To find out the relationship between the possible pairs of employee engagement in public sector banks, the Pearson's product moment correlation is used. The null hypothesis framed for this purpose is "the various factors of employee engagement are not significantly related with the overall employee engagement in the public sector banks".

Table 1: Pearson's Product Moment Correlation (Public Sector Bank Employees)

\begin{tabular}{|c|c|c|c|c|}
\hline Factors & C & S\&B & JS & OEE \\
\hline C & 1 & $0.459^{*}$ & $0.871^{* *}$ & $0.396^{* *}$ \\
\hline S\&B & & 1 & $0.438^{* *}$ & $0.793^{* *}$ \\
\hline JS & & & 1 & $0.625^{* *}$ \\
\hline OEE & & & & 1 \\
\hline
\end{tabular}

** Significant at 1\% level; * Significant at 5\% level

C - Commitment; S\&B - Salary and Benefits;

JS - Job Satisfaction; OEE - Overall Employee Engagement

From Table 1 it is clear that in case of employees working in public sector banks, all the employee engagement factors namely 'Commitment', 'Salary and benefits' and 'Job satisfaction' are significantly related at $1 \%$ level of significance with overall employee engagement. Thus the null hypothesis is rejected and concluded that the various factors of employee engagement are significantly related with the overall employee engagement in public sector banks”.

\section{ii. Private Sector Bank Employees}

To find out the relationship between the possible pairs of employee engagement in private sector banks, the Pearson's product moment correlation is used. The null hypothesis framed for this purpose is "the various factors of employee engagement are not significantly related with the overall employee engagement in the private sector banks”.

Table 2: Pearson's Product Moment Correlation (Private Sector Bank Employees)

\begin{tabular}{|c|c|c|c|c|}
\hline Factors & $\mathrm{C}$ & S\&B & JS & OEE \\
\hline $\mathrm{C}$ & 1 & $0.761^{* *}$ & $0.425 * *$ & $0.651 * *$ \\
\hline S\&B & & 1 & $0.348 *$ & $0.531^{* *}$ \\
\hline JS & & & 1 & $0.611 * *$ \\
\hline OEE & & & & 1 \\
\hline
\end{tabular}


JS - Job Satisfaction; OEE - Overall Employee Engagement

From Table 2, it is clear that in case of employees working in private sector banks, all the employee engagement factors namely 'Commitment', 'Salary and benefits' and 'Job satisfaction' are significantly related at $1 \%$ level of significance with overall employee engagement. Thus the null hypothesis is rejected and concluded that the various factors of employee engagement are significantly related with the overall employee engagement in private sector banks.

6.2 Relating the Employee Engagement Factors with the Demographic and other Variables of the Bank Employees

In this part an attempt is made by the researcher to relate the various employee engagement factors with the demographic and other variables of the bank employees. The demographic variables taken for the present study are gender, age, marital status, educational qualification and monthly income. The other variables considered are years of experience and designation of the bank employees. To relate this ANOVA test is applied and the results are shown as under.

\section{i. Relationship between 'Commitment' and Demographic and other Variables}

To find out the relationship between the employee engagement factor 'Commitment' and the demographic and other variables of the bank employees, ANOVA test is applied. The null hypothesis framed for this purpose is "The employee engagement factor 'Commitment' is not significantly related with the demographic and other variables of the bank employees in public and private sector banks”. The result of the same is shown in Table 3.

Table 1: Commitment and Demographic and other Variables

\begin{tabular}{|c|c|c|c|c|c|}
\hline \multirow{2}{*}{ Variables } & \multirow{2}{*}{$\begin{array}{c}\text { Table } \\
\text { value } \\
\text { at } 5 \% \\
\text { level }\end{array}$} & \multicolumn{2}{|c|}{$\begin{array}{c}\text { Public Sector } \\
\text { Banks }\end{array}$} & \multicolumn{2}{|c|}{$\begin{array}{c}\text { Private Sector } \\
\text { Banks }\end{array}$} \\
\hline & & $\begin{array}{c}\text { 'F' } \\
\text { Value }\end{array}$ & $\begin{array}{l}\text { Res } \\
\text { ult }\end{array}$ & $\begin{array}{c}\text { 'F' } \\
\text { Value }\end{array}$ & $\begin{array}{l}\text { Res } \\
\text { ult }\end{array}$ \\
\hline Gender & 2.62 & 1.299 & NS & 1.501 & NS \\
\hline Age & 2.62 & 5.728 & S & 3.826 & $\mathrm{~S}$ \\
\hline Marital status & 2.62 & 3.481 & S & 2.530 & NS \\
\hline $\begin{array}{c}\text { Educational } \\
\text { qualification }\end{array}$ & 2.62 & 4.588 & S & 9.458 & S \\
\hline $\begin{array}{l}\text { Monthly } \\
\text { income }\end{array}$ & 2.62 & 0.711 & NS & 5.714 & $\mathrm{~S}$ \\
\hline $\begin{array}{c}\text { Years of } \\
\text { experience }\end{array}$ & 2.62 & 1.677 & NS & 2.561 & NS \\
\hline Designation & 2.62 & 3.320 & S & 2.978 & S \\
\hline
\end{tabular}

NS - Not Significant; S - Significant

From Table 3 it is clear that, in case of public sector banks, the calculated value is higher than the table value at 5\% level of significance for the variables age, marital status, educational qualification and designation. Thus the null hypothesis is rejected and concluded that the employees engagement factor 'Commitment' is significantly related to the demographic variables age, marital status and educational qualification of the bank employees and it is also related to the other variable designation.

Likewise in case of private sector banks, the calculated value is higher than the table value at $5 \%$ level of significance for the variables age, educational qualification, monthly income and designation. Thus the null hypothesis is rejected and concluded that the employees' engagement factor 'Commitment' is significantly related to the above stated demographic and other variables of the bank employees.

ii. Relationship between 'Salary and Benefits' and Demographic and other Variables

To find out the relationship between the employee engagement factor 'Salary and Benefits' and the demographic and other variables of the bank employees, ANOVA test is applied. The null hypothesis framed for this purpose is "The employee engagement factor 'Salary and Benefits' is not significantly related with the demographic and other variables of the bank employees in public and private sector banks”. The result of the same is shown in Table 4.

Table 2: Salary and Benefits and Demographic and other Variables

\begin{tabular}{|c|c|c|c|c|c|}
\hline \multirow{2}{*}{ Variables } & \multirow{2}{*}{$\begin{array}{c}\text { Table } \\
\text { value } \\
\text { at 5\% } \\
\text { level }\end{array}$} & \multicolumn{2}{|c|}{$\begin{array}{c}\text { Public Sector } \\
\text { Banks }\end{array}$} & \multicolumn{2}{|c|}{$\begin{array}{c}\text { Private Sector } \\
\text { Banks }\end{array}$} \\
\cline { 3 - 6 } & $\begin{array}{c}\text { Res } \\
\text { ult }\end{array}$ & $\begin{array}{c}\text { 'F' } \\
\text { Value }\end{array}$ & $\begin{array}{c}\text { Res } \\
\text { ult }\end{array}$ \\
\hline Gender & 2.62 & 4.879 & S & 1.354 & NS \\
\hline Age & 2.62 & 1.452 & NS & 3.560 & S \\
\hline Marital status & 2.62 & 0.845 & NS & 1.577 & NS \\
\hline $\begin{array}{c}\text { Educational } \\
\text { qualification }\end{array}$ & 2.62 & 2.435 & NS & 3.981 & S \\
\hline $\begin{array}{c}\text { Monthly } \\
\text { income }\end{array}$ & 2.62 & 2.305 & NS & 0.941 & NS \\
\hline $\begin{array}{c}\text { Years of } \\
\text { experience }\end{array}$ & 2.62 & 3.756 & S & 4.756 & S \\
\hline Designation & 2.62 & 6.781 & S & 2.450 & NS \\
\hline
\end{tabular}

NS - Not Significant; S - Significant

From Table 4 it is clear that, in case of public sector banks, the calculated value is higher than the table value at $5 \%$ level of significance for the variables gender, years of experience and designation. Thus the null hypothesis is rejected and concluded that the employees engagement factor 'Salary and Benefits' is significantly related to the above stated demographic and other variables.

Similarly in case of private sector banks, the calculated value is higher than the table value at $5 \%$ level of significance for the variables age, educational qualification and years of experience. Thus the null hypothesis is rejected and concluded that the employees' engagement factor 'Salary and Benefits' is significantly related to the above stated demographic and other variables of the employees in private sector banks.

\section{iii. Relationship between 'Job Satisfaction' and Demographic and other Variables}

To find out the relationship between the employee engagement factor 'Job Satisfaction' and the demographic and other variables of the bank employees, ANOVA test is 
applied. The null hypothesis framed for this purpose is "The employee engagement factor 'Job Satisfaction' is not significantly related with the demographic and other variables of the bank employees in public and private sector banks". The result of the same is shown in Table 5 .

Table 5: Job Satisfaction and Demographic and other Variables

\begin{tabular}{|c|c|c|c|c|c|}
\hline \multirow{2}{*}{ Variables } & \multirow{2}{*}{$\begin{array}{c}\text { Table } \\
\text { value } \\
\text { at } 5 \% \\
\text { level }\end{array}$} & \multicolumn{2}{|c|}{$\begin{array}{c}\text { Public Sector } \\
\text { Banks }\end{array}$} & \multicolumn{2}{|c|}{$\begin{array}{c}\text { Private Sector } \\
\text { Banks }\end{array}$} \\
\hline & & $\begin{array}{c}\text { 'F' } \\
\text { Value }\end{array}$ & $\begin{array}{l}\text { Res } \\
\text { ult }\end{array}$ & $\begin{array}{c}\text { 'F' } \\
\text { Value }\end{array}$ & $\begin{array}{c}\text { Res } \\
\text { ult }\end{array}$ \\
\hline Gender & 2.62 & 0.233 & NS & 2.112 & NS \\
\hline Age & 2.62 & 1.653 & NS & 1.540 & NS \\
\hline Marital status & 2.62 & 3.514 & $\mathrm{~S}$ & 0.556 & NS \\
\hline $\begin{array}{l}\text { Educational } \\
\text { qualification }\end{array}$ & 2.62 & 2.350 & NS & 3.447 & $\mathrm{~S}$ \\
\hline $\begin{array}{l}\text { Monthly } \\
\text { income }\end{array}$ & 2.62 & 2.955 & $\mathrm{~S}$ & 5.981 & $\mathrm{~S}$ \\
\hline $\begin{array}{c}\text { Years of } \\
\text { experience }\end{array}$ & 2.62 & 2.411 & NS & 4.779 & $\mathrm{~S}$ \\
\hline Designation & 2.62 & 4.690 & $\mathrm{~S}$ & 0.989 & NS \\
\hline
\end{tabular}

NS - Not Significant; S - Significant

From Table 5 it is clear that, in case of public sector banks, the calculated value is higher than the table value at $5 \%$ level of significance for the variables marital status, monthly income and designation. Thus the null hypothesis is rejected and concluded that the employees engagement factor 'Job Satisfaction' is significantly related to the demographic variables marital status and monthly income and other variable designation.

In the same way in case of private sector banks, the calculated value is higher than the table value at $5 \%$ level of significance for the variables educational qualification, monthly income and years of experience. Thus the null hypothesis is rejected and concluded that the employees' engagement factor 'Job Satisfaction' is significantly related to the above stated demographic and other variables of the employees in private sector banks.

\section{RECOMMENDATIONS}

The following are some of the recommendations made for improving employee engagement in banking sector:

1. From the analysis it is clear that in case of public sector bank employees, the factor commitment is moderately related to overall employee engagement. Efforts should be taken to increase the commitment to higher levels. For this strong orientation and stimulation programme must be arranged by the organization on top.

2. In case of private sector bank employees, salary and benefits and job satisfaction are moderately related.
Thus organization must take necessary steps to increase the salary and benefits given to their employees to have higher degree of job satisfaction. For this competence and skill based pay structure can be followed.

3. Every organization must promote and recognize team performance to have better employee engagement.

4. Awards and appreciation must be given to the employees based on their performance which enhances employee engagement.

5. Employee redressal unit can be formed to redress employees in case of intricate situations either private or social which help in improving employee engagement.

6. Everyone likes praise for a job well done. So the top managers must keep employee recognition visible, so that it leads to increased involvement from other coworkers, which motivates employee engagement.

\section{CONCLUSION}

Organizations have to give their employees the freedom to make their work exciting and an environment having an engaged work life. With increase in responsibilities at home and a desire to excel in their careers, employees often get distracted from their work which needs to be taken care of. Employees are the assets of the organization and if they are not given a space whereby they can make a perfect blend of both work and fun, optimum performance from them may be difficult. Thus an organization should realize the importance of employees, more than any other variable, as try to engage them to the utmost possible level by intriguing suitable measures.

\section{FUTURE ENHANCEMENT}

The study can be further extended by considering other factors that induce employee engagement like 'Corporate culture and communication', 'Work environment', 'Relationship with others' and 'Training and development prospects' in the banking sector. Also employee engagement can be measured on a longitudinal basis which clearly shows the extent of employee engagement over a period of years. Besides, a comparative study on employee engagement in any two public sector banks or any two private sector banks can also be undertaken.

\section{REFERENCE}

[1] Neeta Bhatla, "To Study the Employee Engagement Practices and its Effect on Employee Performance With Special Reference to ICICI and HDFC Bank in Lucknow", International Journal of Scientific and Engineering Research, Vol. 2, No.8, Pp. 1-7, 2011.

[2] Denison. D.R., "Corporate Culture and Organizational Effectiveness", New York: Wiley, 1990.

[3] Hafiz Abdur Rashid, Ammar Asad and Mian Muhammad Ashraf, "Factors Persuading Employee Engagement and Linkage of EE to Personal and Organizational Performance”, Interdisciplinary Journal of Contemporary Research in Business, Vol.3, No.5, Pp. 98-108, 2011.

[4] Swatee Sarangi, R.K. Srivastava, "Driving Employee Engagement in Nationalized Banks in India”, International Conference on Economics, Business Innovation, IPEDR Vol.38, Pp.131-134, 2012.

[5] May, D.R. Gilson, R.L. and Harter, L.M., 'The Psychological Conditions of Meaningfulness, Safety and Availability and the 
Engagement of the Human Spirit at Work', Journal of Occupational and Organisational Psychology, Vol.77, Pp.11-37, 2004.

[6] Beverly Little, Philip Little "Employee Engagement: Conceptual Issues”, Journal of Organizational Culture, Communications and Conflict, Vol.10, No.1, Pp.111-120, 2006.

[7] Abdul Khaliq Alvi and Abdus Sattar Abbasi, 'Impact of Organizational Justice on Employee Engagement in Banking Sector of Pakistan", Middle-East Journal of Scientific Research, Vol. 12, No. 5, Pp.643-649, 2012. 